\title{
Impact of Urban Anthropogenic Pressures on the Mangrove Forest of Sainte Marie (East Madagascar)
}

\author{
Andriamparany Rakotomavo', Rita Marie Michele Rasoamanarivo², Polinah Razanajaza1 \\ ${ }^{1}$ Higher Institute of Science, Environment and Sustainable Development, ISSEDD Mangrove Team, University of \\ Toamasina, Toamasina, Madagascar \\ ${ }^{2}$ Department of Geography, University of Antananarivo, Antananarivo, Madagascar \\ Email: andri.savaivo@blueline.mg
}

How to cite this paper: Rakotomavo, A., Rasoamanarivo, R. M. M., \& Razanajaza, P. (2018). Impact of Urban Anthropogenic Pressures on the Mangrove Forest of Sainte Marie (East Madagascar). Open Journal of Forestry, 8, 380-392.

https://doi.org/10.4236/ojf.2018.83024

Received: June 7, 2018

Accepted: July 22, 2018

Published: July 25, 2018

Copyright $\odot 2018$ by authors and Scientific Research Publishing Inc. This work is licensed under the Creative Commons Attribution International License (CC BY 4.0).

http://creativecommons.org/licenses/by/4.0/

\begin{abstract}
This article demonstrates the urban anthropogenic threats and their impacts on Sainte Marie (Eastern Madagascar) mangrove ecosystem. In addition to conducting interview with 158 residents, floristic inventories were carried out in order to compare the mangrove structure between a control site and another one that was impacted by Belle Vue dyke (south of the District downtown) rehabilitation. From 2003 to 2014, the island of Sainte Marie lost $0.47 \%$ per year of its mangrove area. $87 \%$ of the harvested resources from this ecosystem are fish products and are related to human nutrition. The mangrove is used as a dumping ground for liquid and solid waste in the lots of Saint Joseph and La Pointe. Defecation in the open air is topical under the island's mangrove forest. A very weak resilience of the mangrove impacted by the rehabilitation of Belle Vue dyke was noted. Indeed, regenerations of Bruguiera gymnorrhiza and Ceriops tagal have struggled to rebuild. The total height and diameter of impacted trees decreased by $37.2 \%$ and $44.3 \%$, respectively. The development of an updated urban master plan, including mangroves in the related zoning process is an imperative measurement for the conservation and/or valuation of existing lots.
\end{abstract}

\section{Keywords}

Mangrove, Sainte Marie, Urban Planning, Urban Threats, Resilience, Mangrove Regeneration

\section{Introduction}

With 172 ha of mangrove forest, equivalent to $4 \%$ of mangroves on the East 
coast of Madagascar and $0.6 \%$ of the entire territory of Sainte Marie island, the mangrove of the latter is in fourth position in terms of area, after the Irodo, Ambodivahibe and Rigny complex, which includes 90\% of mangroves in eastern Madagascar (Rakotomavo, 2018; Rakotomavo, Rasoamanarivo, Andrianoelisoa, Razafimamonjy, Razafinarivo, Razanajaza, Rafilipo, Betsiafindra, Maro, Ralaizandriarison, Randriamiarina, Sangotra, Randrianarisoa, \& Rakotoson, 2018; Rakotomavo \& Rasoamnarivo, 2018). Except the few works carried out by Rakotomavo \& Rasoamanarivo, 2018; Cétamada, 2014; Andriantsoa, 2017, the island's mangrove lots were little studied. However, this ecosystem of eastern Madagascar holds an important place (Andrianoelisoa, 2017) and a multitude of issues, both ecologically and socio-economically and territorial planning (Rakotomavo, 2018). Geographically located in the Indian Ocean, the Malagasy island of Sainte Marie is a tourist town of 27,200 inhabitants and dense of 100 inhabitants $\mathrm{km}^{-2}$ (Rasoamanarivo, 2017). Growing in a warm (average annual temperature of $25.5^{\circ} \mathrm{C}$ ) and humid (3369 $\mathrm{mm}$ of annual rain) tropical climate where there is no dry season (Rasoamanarivo, 2017), its mangrove is confronted with a dynamics of urban planning where the stakes of urbanization on the sites with Mangrove are important. In addition to the demographic dynamics characterized by the coming and going of resident and non-resident populations including tourists, traders and other local and foreign investors, the rehabilitation of Belle Vue dyke connecting the Center and the South of the island in 2013 disrupted the hydro-dynamic mechanism of the Ikoa and Marorano mangrove lots. This article attempts to identify the anthropogenic threats on this ecosystem, in urban development including the process of territorial occupation and the construction of road infrastructures. The objective is to analyze the impact of urban phenomena on the preservation of existing mangrove lots.

\section{Materials and Methods}

Interview with 158 residents of the island's mangroved lots was carried out in August 2016. This number corresponds roughly to $20 \%$ of the direct user households of the Mangrove (e.g. fishermen, occupants of mangrove sites, ...) and its resources. The questionnaire used was focused on the various anthropogenic uses of mangrove resources, showing the quantities harvested and their objectives.

Interviews with municipal and territorial officials of the District have provided information on the current management and development of the city. Direct observations on the state of the lots concerned by the backfilling and clearing work were particularly carried out with the aim of photographing and mapping them under Geographical Information System. Google Earth public images of 2013 and 2015 were used during the monitoring of the spatio-temporal evolution of the mangrove.

To evaluate the impact of the rehabilitation of Belle Vue dyke on the peripheral mangrove lots, an analysis of the horizontal and vertical structure of the trees was carried out, respectively in Marorano and Ambodiforaha (Figure 1), 


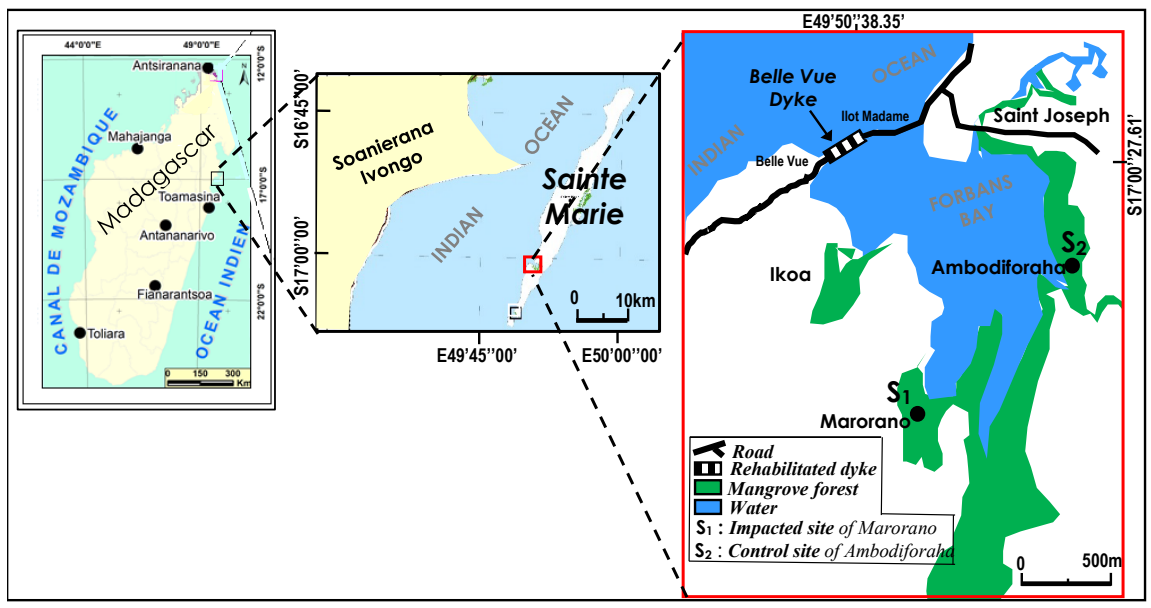

Figure 1. Location map of Sainte Marie and sites studied.

two sites impacted $\left(\mathrm{S}_{1}\right)$ and not impacted (control site $\mathrm{S}_{2}$ ) by the disturbances linked to said rehabilitation. Thirty-five plots of $10 \mathrm{~m} \times 10 \mathrm{~m}$ per site were observed and measured directly in terms of:

- Natural regeneration, which corresponds to live mangrove seedlings less than $1 \mathrm{~m}$ high and whose average stem diameter is less than $1.5 \mathrm{~cm}$ (Rakotomavo, 2010). Regenerated individuals within each plot were identified for each species. An average number was thus obtained and this represents the average of the regeneration density of all the plots of each site, such as:

$$
n=\frac{100}{35} \sum_{n 1}^{n 35}
$$

where:

$$
\begin{aligned}
& n=\text { average density regenerations (live seedlings ha } \mathrm{h}^{-1} \text { ) } \\
& n 1=\text { number of live seedlings counted in plot } \mathrm{n}^{\circ} 1 \\
& n 35=\text { number of live seedlings counted in plot } \mathrm{n}^{\circ} 35
\end{aligned}
$$

- Density of seed trees, which corresponds to the number of live mature individuals more than $1 \mathrm{~m}$ high (Rakotomavo, 2010), with a stem more than 1.5 $\mathrm{cm}$ in diameter. Seed individuals within each plot were identified for each species. A number $d$ has therefore been obtained; this corresponds to the average density of all the plots of each site, such as:

$$
d=\frac{100}{35} \sum_{d 1}^{d 35}
$$

where:

$d=$ average density of seed trees (live mature trees $\mathrm{ha}^{-1}$ )

$d 1=$ number of seed trees in plot $\mathrm{n}^{\circ} 1$

d35 $=$ number of seed trees in plot $\mathrm{n}^{\circ} 35$

- Regeneration rate $r$ (adapted from Rothe, 1964) the average for all 35 plots per site is given by the formula:

$$
r=\frac{1}{35} \sum_{\frac{1000 n 1}{d 1}}^{\frac{100 n 35}{d 15}}
$$


where:

$$
\begin{aligned}
& r=\text { average regeneration rate in\% } \\
& n 1=\text { number of regenerations (live seedlings ha } \mathrm{h}^{-1} \text { ) in plot } \mathrm{n}^{\circ} 1 \\
& d 1=\text { number of seed trees (live mature trees } \mathrm{ha}^{-1} \text { ) in plot } \mathrm{n}^{\circ} 1 \\
& n 35=\text { number of regenerations (live seedlings ha } \mathrm{h}^{-1} \text { ) in plot } \mathrm{n}^{\circ} 35 \\
& d 35=\text { number of seed trees (live mature trees ha } \mathrm{h}^{-1} \text { ) in plot } \mathrm{n}^{\circ} 35
\end{aligned}
$$

with:

if $r>1000 \%$ : very strong regeneration

if $300 \%<r<1000 \%$ : strong regeneration

if $100 \%<r<300 \%$ : medium regeneration

if $r<100 \%$ : weak regeneration

- Average total height of trees $h$, which is the sum of different heights such as height of aerial roots, that of the bole, and crown, which were measured for each site, plot, and species. The average height $h$ is thus given by the formula:

$$
h=\frac{100}{35} \sum_{h 1}^{h 35}
$$

with:

$$
\begin{aligned}
& h=\text { average total height of mature trees }(\mathrm{m}) \\
& h 1=\text { average total height of mature trees in plot } \mathrm{n}^{\circ} 1(\mathrm{~m}) \\
& h 35=\text { average total height of mature trees in plot } \mathrm{n}^{\circ} 35(\mathrm{~m})
\end{aligned}
$$

- Physiognomic resilience of trees, which was assessed visually from leaf color (scale: yellowing, greenness) and vividness of tree (scale: standing dying, withering, alive).

- Average mortality rate of trees $m r$, which corresponds to the percentage of standing mature dead trees per hectare (compared with the total number of live mature trees), such as:

$$
m r=\frac{1}{35} \sum_{\frac{100 m 35}{N 1}}^{\frac{100 m 5}{N 1}}
$$

with:

$$
\begin{aligned}
& m r=\text { average mortality rate of mature trees (\%) } \\
& m 1=\text { number of dead mature trees in plot } \mathrm{n}^{\circ} 1 \\
& m 35=\text { number of dead mature trees in plot } \mathrm{n}^{\circ} 35 \\
& N 1=\text { total number of live mature trees in plot } \mathrm{n}^{\circ} 1 \\
& N 35=\text { total number of live mature trees in plot } \mathrm{n}^{\circ} 35
\end{aligned}
$$

\section{Results}

\subsection{A Coveted Urban Resource without Updated Management Tools}

More than a dozen natural resources are taken from mangrove lots in Sainte Marie (Table 1). $87 \%$ harvested samples are fish products and are related to human nutrition. $2 \%$ to $90 \%$ of these products are self-consumed by the fishing household, depending on the trout fished; $49 \%$ of uses consist of fishing for 
Table 1. The 9 main resources taken from the mangrove lots of Sainte Marie.

\begin{tabular}{ccc}
\hline Resources harvested & Anthropogenic uses & \% of uses \\
\hline Terebralia palustris & $90 \%$ self-consumption, 10\% sale & 30 \\
Crabs & 70\% self-consumption, 70\% sale & 19 \\
Shrimps & $5 \%$ self-consumption, 95\% sale & 8 \\
Construction wood & Construction, enclosure & 3 \\
Prawn & 2\% self-consumption, 98\% sale & 7 \\
Firewood & Combustible & 0.5 \\
Fishes & $60 \%$ self-consumption, 40\% sale & 2 \\
Timber & Carpentry, crafts & 0.5 \\
Mangrove tree leaves & Phyto-medecine & 8 \\
\hline
\end{tabular}

crabs and Terebralia palustris, which, with respectively an average density of 20,000 and 48,000 individuals $\mathrm{ha}^{-1}$ all sizes combined, are quite abundant in the Ambodiforaha control site. $19 \%$ of the reported uses are related to mangrove crab harvesting, compared to $8.5 \%$ for phyto-medicine and timber. The extractions of wood for fuel and carpentry/craft respectively represent only $8 \%$ and $0.5 \%$ of total uses. The use of timber collecting approximates $3 \%$.

In addition to forestry and sectoral texts in force no updated management tool governs these various harvesting and anthropogenic uses. The Management Transfer document and the management plan for the mangrove lots concerned by the harvesting date back to 2003. No update of these two basic tools has been carried out so far (situation of September 2017). As a result, the implementation of local resource management rules, known as dina, remains obsolete. This situation would legitimize the actions taken by residents, regardless of their social and ecological scope.

\subsection{Land and Management Issues around Mangrove Lots}

As part of the national estate, according to the land and forest regulations in force, some mangrove lots of Sainte Marie, like Saint Joseph and Ikoa where nearly 3 and 2 ha are concerned, are currently the object of land grabbing from the inhabitants. Backfilling works (18\% of recorded pressure cases) followed by clearing of mangroves ( $75 \%$ of cases) are visible at these sites where buildings made of vegetal and hard materials occupy the banks of the channels. On the side of Saint Joseph, back mangrove, the salt flat is the subject of coconut plantation and land leveling for occupancy purposes. In Ikoa, the transformation of mangrove sites into private land is topical, although the mangrove belongs, in principle, to the state. To this land occupation is added a certain number of urban planning issues such as those relating to the evacuation and drainage of water (sewage, rain and tide), pollution related to open defecation, and the discharges of liquid and solid waste (6\% of the residents of Pointe and Saint Joseph are involved), as well as public health problems (malaria caused by mosquitoes, 
urban sanitation).

\subsection{Failure to Integrate the Environmental Dimension into Urban Infrastructure Construction Works}

In 2013, the Ilot Madame and Belle Vue dyke, approximately $200 \mathrm{~m}$ long, located $1 \mathrm{~km}$ south of the city center (National Road \#21), had been rehabilitated for better communication between the northern part and the center of the island. The inlet and outlet of the waters at the dyke had experienced disturbances during the works. In fact, according to the environmental control and monitoring report prepared by the (Service Régional de l'Environnement, 2014) of Fénérive Est dated April 5, 2014, consolidated by the one carried out by (Duchene, 2014) on June 4, 2014, as well as according to the Cétamada technical report (Cétamada, 2014), the five channels which ensured the inlet and outlet and the water exchanges at the level of the dyke in question were completely obstructed. The very low salinity of the water $\left(0.0001\right.$ to $0.0016 \mathrm{~g} \cdot \mathrm{l}^{-1}$ in the $800 \mathrm{~m}$ east of the dyke (Cétamada, 2014)), as well as the rising of the water level in Forbans Bay had adverse effects on the mangroves in the area: yellowing and leaf fall, tree decay, and the death of a number of aquatic animals including fish. These findings were confirmed by (Cétamada, 2014; Service Régional de l'Environnement, 2014; Duchene, 2014), six months after the total closure of the five channels.

\subsection{Very Low Resilience of Mangroves}

In November 2017, i.e. 47 months after the beginning of the rehabilitation works, the following findings could be established after comparison between the Ambodiforaha control site $\left(\mathrm{S}_{2}\right)$ and the impacted site $\left(\mathrm{S}_{1}\right)$ of Marorano. It should be noted that the closing of the inlet and outlet of the waters lasted 6 months in a row, with a small opening of $1 \mathrm{~m}$ of width $\times 1 \mathrm{~m}$ of height towards the third month, after negotiation with the company in rehabilitation (Rakotomavo, Rasoamanarivo, Andrianoelisoa, Razafimamonjy, Razafinarivo, Razanajaza, Rafilipo, Betsiafindra, Maro, Ralaizandriarison, Randriamiarina, Sangotra, Randrianarisoa, \& Rakotoson, 2018). Seawater and freshwater could only find their initial exchange mechanism as of the seventh month, since July 2014.

\subsubsection{Difficult Regeneration}

With a regeneration rate of $146 \%$, the impacted site of Marorano presents an average recovery, according to the Rothe scale (Rothe, 1964). This value is, however, negligible when compared with that of the Ambodiforaha control site where the rate is 208 times higher (Table 2). Rates per species are less than $100 \%$ at Marorano; at a rate of $18 \%$, Bruguiera gymnorhiza is the least regenerated species (against $\mathrm{r}=28,500 \%$ at Ambodiforaha), followed by Lumnitzera racemosa (22\%) and by Ceriops tagal (30\%). Sonneratia alba does not regenerate, although this species regenerates well $(\mathrm{r}=500 \%)$ at the control site.

It should be noted that Ceriops tagal and Lumnitzera racemosa have no regeneration at the control site, whereas both species respectively have a regeneration rate of $30 \%$ and $22 \%$ at Marorano. 
Table 2. Regeneration rates (\%) after 6 months of canal filling and 41 months of restoration of water flows.

\begin{tabular}{ccc}
\hline Regenerated species & Ambodiforaha control site $\left(\mathrm{S}_{2}\right)$ & Marorano impacted site $\left(\mathrm{S}_{1}\right)$ \\
\hline Rhizophora mucronata & 1334 & 77 \\
Sonneratia alba & 500 & 0 \\
Bruguiera gymnorrhiza & 28,500 & 18 \\
Lumnitzera racemosa & 0 & 22 \\
Ceriops tagal & 0 & 30 \\
Total & 30,334 & 146 \\
\hline
\end{tabular}

\subsubsection{High Mortality and Low Density of Live Trees}

With a ratio of 2 Rhizophora mucronata trees dead out of 100 live at Ambodiforaha control site (ratio $=0.02$, i.e. $\mathrm{mr}=2 \%$ ), Marorano records more, i.e. 55 standing dead for 33 alive (ratio $=1.67$, i.e. $\mathrm{mr}=16.7 \%$ ). The impacted site thus recorded 83.33 times more Rhizophora $m$ dead mature trees than the non-impacted site, and this, 47 months after the start of the rehabilitation work on Ilot Madame-Belle Vue dyke (where 5 channels had been blocked for the first 6 months), i.e. 41 months after the restoration of the water inlet and outlet mechanism.

The two sites, with the Bruguiera gymnorrhiza species, have the same density in terms of living trees and dead trees, (1700 individus $\left.\mathrm{ha}^{-1}\right)$. In other words, $100 \%$ of Bruguiera g. mature seedlings of the Marorano impacted site have all withered away, after 47 months of the start of the dyke closure and 41 months after recovery of the water flows. It should be noted, however, that with 1700 living mature trees $\mathrm{ha}^{-1}$, the impacted site of Marorano has become 47 times richer in Bruguiera g. than the control site (Figure 2).

Between 2013 and 2015, the dead mangrove area accounted for $4.7 \%$ of the entire Marorano lot. In other words, the area lost $2.35 \% \cdot \mathrm{an}^{-1}$ of its mangrove in 2 years.

\subsubsection{Selective Cutting of Trees by Local Residents}

The Bruguiera gymnorrhiza standing dead trees were all collected by local residents for construction and fuel purposes (tc $=100 \%$ ). Being a straight and moderately calorific tree, according to $89 \%$ and $65 \%$ of the people surveyed, 1700 dead trees of Bruguiera g. are subject to selective cutting in the impacted site of Marorano. Rhizophora mucronata woods are less popular than other mangrove trees; $2.5 \%$ of residents only call them high-calorific fuels. Having ramified stems and rarely quite straight, this species is not appreciated in terms of construction; their height rarely exceeds $4 \mathrm{~m}$, hence the low harvest of 200 standing dead.

In addition to harvesting standing dead trees, selective cutting also exists, both at the control site and at the impact site (Figure 3). This form of pressure is in the form of cutting live trees perpetrated by local residents. 500 and 1200 mature individuals of Rhizophora m. and of Bruguiera g. per hectare are taken from 

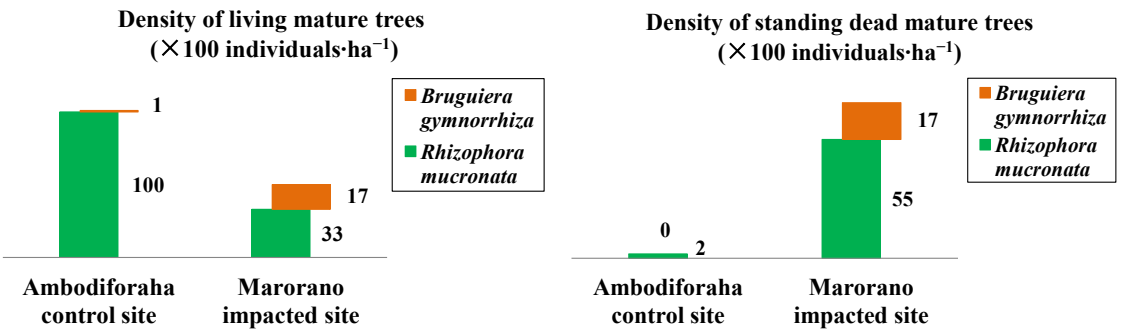

Figure 2. Density of live (left) and dead (right) mature trees after 6 months of canal filling and 41 months of water flow restoration-case of Rhizophora m. and Bruguiera g.

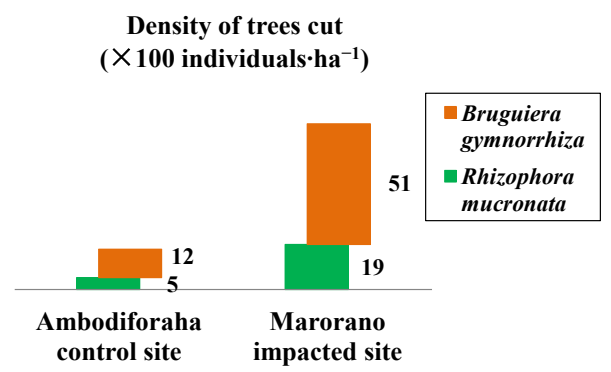

Figure 3. Density of Rhizophora $\mathrm{m}$. and Bruguiera g. trees, object of cutting by residents.

Ambodiforaha, respectively, compared with 1900 and 5100 individuals per hectare at the impacted site of Marorano. In other words, the anthropogenic harvest is relatively 4 times greater where residents see a dying mangrove. According to $79 \%$ of respondents, they rush to fell trees before it is too late to value them in construction and cooking.

\subsubsection{Tree Stunting}

47 months after the rehabilitation of the dyke, the average size of the trees is experiencing a significant loss of growth, which is estimated at $-37.2 \%$ and $-44.3 \%$ for breast-height diameter and total height, respectively (Figure 4). Thus, there is a stunting of mangroves at $S_{1}$.

\section{Discussions}

\subsection{Pressures or Socio-Economic Valuations?}

According to (Rasoamanarivo, 2017), the annual spatial losses at the level of all Sainte Marie mangrove lots amount to $0.47 \%$. This rate is still low if we refer to national clearing rates of $1.34 \%$ (Giri \& Muhlhausen, 2008) and $1.06 \%$ (Jones, Glass, Gandhi, Ravaoharinorotshihoarana, Carro, Benson, Rakoto-Ratsimba, Giri, Randriamanantena, \& Cripps, 2016). This annual spatial decline is also small when compared to the global surface loss of $1.75 \% \cdot \mathrm{yr}^{-1}$ (Valiela, Brown, \& York, 2001) over the past two decades. However, it is quite significant if one refers to the case of Rigny $\left(0.2 \%\right.$ over thirty years, or $0.006 \% \cdot \mathrm{yr}^{-1}$ between 1986 and 2016 , according to (Andrianoelisoa, 2017)), one of the largest mangrove lots of the Malagasy East (Rakotomavo, 2018). Moreover, according to (Mandimbinirina, 2017), the small mangrove of Foulpointe (Eastern Madagascar) loses $0.15 \%$ of its 

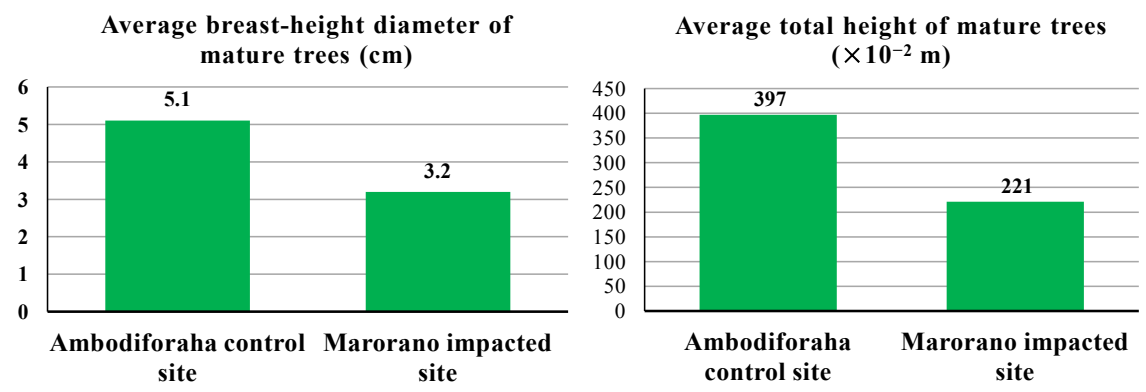

Figure 4. Diameter at breast height (left) and average total height (right) of trees, dead and alive together, after 6 months of canal filling and 41 months of water flow restoration.

surface annually, a low figure compared to that of Sainte Marie, but which would be alarming if one refers to its small size ( $<2$ ha according to (Rakotomavo, 2018; Rakotomavo, Rasoamanarivo, Andrianoelisoa, Razafimamonjy, Razafinarivo, Razanajaza, Rafilipo, Betsiafindra, Maro, Ralaizandriarison, Randriamiarina, Sangotra, Randrianarisoa, \& Rakotoson, 2018; Rakotomavo \& Rasoamanarivo, 2018)), its regenerative potential and the threats towards it (Mandimbinirina, 2017).

Given the socio-economic services offered by the mangroves of Sainte Marie on the one hand, and the low rate of spatial degradation of the latter, on the other hand, one wonders if the term "pressure" would be appropriate. Should we not rather speak of "socio-economic valuation", since up to now, the harvesting of wood and fauna resources made by local residents has little effect on the integrity of the ecosystem; on the contrary, the valuation of dead wood, as well as the anticipated removal of Bruguiera gymnorrhiza trees following the ecological damage caused by the rehabilitation of Ilot Madame-Belle Vue dyke (see 3.4.3.), would constitute a form of rational management of mangroves of the area. Lebigre confirms that one of the criteria for assessing Bruguiera gymnorrhiza lies in the straight quality of its stem. This species is thus coveted in construction, giving standard poles and posts of $4-5 \mathrm{~m}$.

Balance between the stock, the regeneration process, as well as anthropogenic harvesting, however, must be monitored if we want to keep the integrity of the ecosystem. As the percentage of use of mangrove woods depends on the existence of sources of wood other than mangroves (Razakanirina, 2016), this balance could be maintained in favor of these species thanks to the existence of Grevillia banksii, Eucalyptus sp. and Melaleuca quinquenervia on the mainland, near the villages (Rasoamanarivo, 2017). Hence the low utilization rate of $3 \%$ of mangrove wood in construction in Sainte Marie compared to $66.7 \%$ to $87.5 \%$ in the Tsiribihina delta, in Madagascar south-west part (Razakanirina, 2016).

The occupation and backfilling of mangrove areas perpetrated by residents has a problem of legitimacy and legality. Indeed, the 2005 land law on acquisitive prescription, as well as the relative legitimacy of a de facto occupation, seems to justify these acts. In addition, the lack of urban planning tools such as the updated urban plan would admit that the occupants of the mangrove areas are right, at least in case of prohibition by the city authorities. There is no current 
reference or zoning on urban planning in Sainte Marie; this would justify de facto occupations followed by clearing, backfilling and construction undertaken by local residents.

Still related to this lack of updated planning tools, the territorial and urban authorities have no benchmark for decisions relating to the management of mangrove areas. Conflicts of competence between the Department of Ecology, the Environment and Forests, the regional authorities, the grassroots associations in charge of managing mangrove lots, the town hall, and the Fokontanys (the smallest administrative subdivision in Madagascar), arise even during the issue of "authorizations" for the occupations in question. In this way, can one speak of pressure, illegality and/or illegitimacy of the acts perpetrated by the occupants of the mangrove sites? Do not these legal loopholes and shortcomings in the city administration constitute a gateway to the degradation of the mangrove ecosystem?

\subsection{Mechanism of Natural Succession and Regeneration}

The limited presence of Bruguiera gymnorrhiza within the control and impacted sites (respectively 1 Bruguiera g. for 100 Rhizophora m. and 17 Bruguiera g. for 33 Rhizophora $m$.) would be linked to the facies succession process described by (Rakotomavo, 2010). In a bay such as Ambodiforaha and Marorano where wave strength is more attenuated and the sedimentation process is muddier, Rhizophora mucronata predominates. According to (Razakanirina, 2016; Tostain, 2010; Kathiresan \& Bingham, 2001; Kathiresan, Rajendran, \& Thangadurai, 1996), Bruguiera g. prefers compact sand-silty stations with a salinity of 15 to 45 g. $\mathrm{l}^{-1}$, with an immersion of short duration but regular. Referring to the water salinity values of 0.0001 to $0.0016 \mathrm{~g} \cdot \mathrm{l}^{-1}$ (Cétamada, 2014) during the closure of canals supplying Forbans Bay, the species could not survive. The rise of the bay waters is about 0.2 to $0.6 \mathrm{~m}$ (according to $92.3 \%$ of the respondents) and the increase of the water level upstream of the inner river (Cétamada, 2014; Service Régional de l'Environnement, 2014) resulted in the permanent submergence of Bruguiera g., resulting in their decline. The restoration of the waters inlet and outlet after 6 months of closure could not ensure the restoration of the initial structure of the Marorano mangrove. The measurement dated November 23th, 2017 shows a salinity of $29 \mathrm{~g} \cdot \mathrm{l}^{-1}$, i.e. a salt concentration within the range given by (Razakanirina, 2016; Tostain, 2010; Kathiresan \& Bingham, 2001; Kathiresan, Rajendran, \& Thangadurai, 1996).

But salinity is not the only parameter involved in favor of the installation of Bruiguiera g. Others, such as, the substrate (sandy-muddy to compact according to (Razakanirina, 2016), against sand-predominantly colloidal clay in Marorano), the overall forest atmosphere (shading, exposure...) are also important. Indeed, according to (Rakotomavo, 2010), the gradual and successive invasion of Rhizophora, then of Bruguiera is linked to ecological conditions such as shading, salinity, regularity of drainage and flooding (Rakotomavo \& Fromard, 2010; Randriamboavonjy \& Rakotomavo, 2012), the phenomenon of "fattening" (Le- 
bigre, 1984) and the existence of shelter or not against strong waves. Bruguiera gymnorhiza, as well as Ceriops tagal, associate very often with Rhizophora mucronata. The species prefers salt-free sites where the mud layer is substantial (Espaces, 2000). Its spatial distribution is thus limited to the scale of the zone, despite their potential for human use.

Bruguiera and Ceriops rarely form mono specific spatial entities such as $A v i-$ cennia or Rhizophora. Preferring well-lit stations (Razakanirina, 2016), Ceriops tagal is quasi-absent in the control site, while traces of cutting and regeneration of this species could be observed in the impacted site of Marorano. In other words, the death of the trees at the impacted site favored the lighting of the site and the reappearance of Ceriops tagal, which eclipsed with the densification of Rhizophora mucronata and of Bruguiera gymnorrhiza at the level of $\mathrm{S}_{2}$.

The residents thus benefited natural succession and regeneration process to source firewood and construction. Before the rehabilitation of the dyke, the inner area was dominated by Rhizophora mucronata, with a few scattered Bruguiera gymnorrhiza and Ceriops tagal trees. The cuts made by the residents would have occurred as soon as they noticed the death of Bruguiera and of $\mathrm{Ce}$ riops. The thinning of the $\mathrm{S}_{1}$ mangrove, 41 months after the restoration of the water flows, allowed some regeneration of Ceriops to settle again.

\section{Conclusion}

Sainte Marie mangrove, especially that of the urban lots in the Center-South of the island, is subject to various forms of human use. It is not only a place to harvest fish and timber resources, but it is also affected by a crucial lack of updated city management tools. Being still weak in terms of annual spatial recession, the pressure weighing on this urban ecosystem is a dualism between legitimacy and legality. The de facto occupation of the mangrove sites, as well as the harvesting of resources via the valuation of dead wood, would become more and more problematic in the absence of a legal-technical reference framework that formalizes these acts. The development of an updated master plan, including the mangroves in the zoning process, is a measurement imperative for a better conservation and/or valuation of the existing lots.

The study shows that, despite the recovery of initial hydro-dynamic and sedimentation mechanisms, the mangrove lots impacted by the rehabilitation of the Ilot Madame-Belle Vue dyke are struggling to regain their initial ecological balance. The resilience of these lots in terms of regeneration and vertical and horizontal structures is very weak, so that the habitat of sensitive species such as Bruguiera gymnorrhiza and Ceriops tagal is disturbed. The death of these species has favored their exploitation by local residents for socio-economic development purposes.

\section{Conflicts of Interest}

The authors declare no conflicts of interest regarding the publication of this paper. 


\section{References}

Andrianoelisoa, R. H. (2017). Etude des valorisations durables du potentiel en biomasse de la mangrove de la Baie de Rigny du District d'Antsiranana II (63 p.). Mémoire de Master. Faculté des Lettres et Sciences Humaines, Mention Géographie, Université d'Antananarivo.

Andriantsoa, A. J. (2017). Etat des lieux sur les mangroves de l'île Sainte Marie afin de contribuer au renforcement de la gestion des ressources à Forbans (62 p.). Mémoire d'ingéniorat. ESSA, Université d'Antananarivo.

Cétamada (2014). Rapport sur la mangrove de Sainte Marie, travaux sur la digue îlot Madame. Association Cétamada.

Duchene, J. J. (2014). Mission d'évaluation et de mise en place d'un plan de réhabilitation, mangrove de la baie des Forbans, île Sainte Marie. Rapport de mission.

Espaces (2000). Mangroves et arrière-mangroves (No. 2, 21 p.). Dossiers Techniques d'Espaces.

Giri, C., \& Muhlhausen, J. (2008). Mangrove Forest Distributions and Dynamics in Madagascar (1975-2005). Sensors, 8, 2104-2117. https://doi.org/10.3390/s8042104

Jones, T. G., Glass, L., Gandhi, S., Ravaoarinorotsihoarana, L., Carro, A, Benson, L., Rakoto Ratsimba, H., Giri, C., Randriamanatena, D., \& Cripps, G. (2016). Madagascar's Mangroves: Quantifying Nation-Wide and Ecosystem Specific Dynamics, and Detailed Contemporary Mapping of Distinct Ecosystems. Remote Sensing, 8, 1-30. https://doi.org/10.3390/rs8020106

Kathiresan, K., \& Bingham, B. L. (2001). Biology of Mangroves and Mangrove Ecosystems. Advances in Marine Biology, 40, 81-251.

https://doi.org/10.1016/S0065-2881(01)40003-4

Kathiresan, K., Rajendran, N., \& Thangadurai, G. (1996). Growth of Mangrove Seedlings in Intertidal Area of Vellar Estuary Southeast Coast of India. Indian Journal of Marine Sciences, 25, 240-243.

Lebigre, J. M. (1984). Problématiques de recherche sur les marais maritimes de Madagascar en vue de leur protection et leur aménagement. Revue de Géographie, 44, 45-74.

Mandimbinirina, D. S. (2017). Caractérisations ethnoécologiques de la petite mangrove de la Commune Rurale Mahavelona Foulpointe, une zone humide à potentiel élevé sans gestionnaire (78 p.). Mémoire de Master II en Sciences, Environnement et Développement Durable. ISSEDD Université de Toamasina.

Rakotomavo, A., \& Rasoamanarivo, R. M. M. (2018). La mangrove de Sainte Marie, une porte d'entrée en matière d'occupation illicite de terrains urbains. Actes du Colloque International sur le Développement, Espace, Territoire et Changement Climatique. Antananarivo, CIRAD-Mention Géographie-Université d'Antananarivo (In Prep)

Rakotomavo, A. (2010). Etat des lieux et dynamique de la mangrove du delta de Mangoky-sud-ouest de Madagascar (151 p.). Thèse de doctorat ès Sciences Agronomiques, Université d'Antananarivo.

Rakotomavo, A. (2018). Les mangroves de l'Est malgache: potentiels écologiques et pressions. Actes du Colloque International sur les mangroves des îles de l'Océan Indien occidental: dynamique, pressions, gestions. Mahajanga, MESUPRES-IRD. (In Prep)

Rakotomavo, A., \& Fromard, F. (2010). Dynamics of Mangrove Forests in the Mangoky River Delta, Madagascar, under the Influence of Natural and Human Factors. Forest Ecology and Management, 259, 1161-1169.

https://www.researchgate.net/publication/229110346_Dynamics_of_mangrove_forests 
_in_the_Mangoky_River_delta_Madagascar_under_the_influence_of_natural_and_hu man_factors

Rakotomavo, A., Rasoamanarivo, R. M. M, Andrianoelisoa, R. H., Razafimamonjy F., Razafinarivo, O. H., Razanajaza, P., Rafilipo, L. A., Betsiafindra, J. M., Maro, C. A, Ralaizandriarison, J. C., Randriamiarina, R. V., Sangotra, A. D., Randrianarisoa, A. H., \& Rakotoson, M. F. (2018). Carte d'identité des mangroves de l'Est malgache. Actes du Colloque International sur les mangroves des îles de l'Océan Indien occidental: dynamique, pressions, gestions. Mahajanga, MESUPRES. (In Prep)

Randriamboavonjy, J. C., \& Rakotomavo, A. (2012). Les sols du delta de Mangoky (Sud-Ouest malgache): Leurs caractéristiques physico-chimiques sous différents faciès de mangrove. Madamines, 4, 62-77.

http://madarevues.recherches.gov.mg/?Les-Sols-du-delta-de-Mangoky-Sud

Rasoamanarivo (2017). La mangrove de Sainte Marie, un écosystème aux enjeux multiples (65 p.). Mémoire de Master. Faculté des Lettres et Sciences Humaines, Mention Géographie, Université d'Antananarivo.

Razakanirina, H. (2016). Les mangroves de Madagascar: Utilisation des ressources en bois, caractéristiques anatomiques du bois et vulnérabilité écologique par rapport au changement climatique (Cas des mangroves du delta de Tsiribihina et de la Réserve de Biosphère de Sahamalaza) (177 p.). Thèse de doctorat en Sciences de la vie et de l'Environnement-Sciences du végétal, Université d'Antananarivo.

Rothe, P. L. (1964). Régénération naturelle en forêt tropicale: le Dipterocarpus dyeri (Dau) sur le versant cambodgien du golfe du Siam. Bois et Forêt des Tropiques, 8, 386-397

Service Régional de l'Environnement (2014). Rapport de mission de contrôle et de suivi environnemental des travaux d'aménagement des infrastructures routières et portuaires de l'île Sainte Marie. DREEF Analanjirofo Sainte Marie.

Tostain, S. (2010). Les espèces de palétuviers dans les mangroves de Tuléar (32 p.). Formad Environnement.

Valiela, I., Bowen, J. L., \& York, J. K. (2001). Mangrove Forests: One of the World's Threatened Major Tropical Environments. Bioscience, 51, 807-815. https://doi.org/10.1641/0006-3568(2001)051[0807:MFOOTW]2.0.CO;2 